Simon Vodrey, $\mathrm{PhD}$

School of Journalism \& Communication

Carleton University

svodrey@hotmail.com

\title{
Political Marketing, Tribal Marketing, \& the Two-Way Flow of Influence
}

\section{Abstract:}

Political marketing holds that marketing has penetrated nearly all aspects of politics and that political marketers superimpose the strategies and tactics of commercial marketers onto the realm of politics. While this pattern of influence has dominated the literature, some have recently suggested that the pattern of influence between politics and marketing may well be in the process of evolving. Building on the works of Sasha Issenberg (2012), Clive Veroni (2014), Daniel Kreiss (2016) and Bruce I. Newman (2016), I examine the extent to which the flow of influence and innovation between commercial and political marketers may be bidirectional and therefore could be seen as indicative of a two-way street with bidirectional interplay between commercial and political marketers rather than as a one-way street with one-way traffic from commercial to political marketers. The example I use to investigate this subject is tribal marketing.

My analysis proceeds in the following manner: First, I establish the basics of tribal marketing. Second, relying upon the results from thirty-three (33) in-depth elite interviews with political marketers, market researchers, political researchers, pollsters and commercial marketers from Canada, the United States, and New Zealand, I examine how tribal marketing is becoming a more recognizable, commonplace and effective way of marketing and how political marketers who are more familiar with this practice are better at building and mobilizing tribes than are commercial marketers. 


\section{Political Marketing, Tribal Marketing, \& the Two-Way Flow of Influence}

Political marketing holds that marketing has penetrated nearly all aspects of politics and that political marketers superimpose the strategies and tactics of commercial marketers onto the realm of politics. While this pattern of influence has dominated the literature, some have recently suggested that the pattern of influence between politics and marketing may well be in the process of evolving. Building on the works of Sasha Issenberg (2012), Clive Veroni (2014), Daniel Kreiss (2016) and Bruce I. Newman (2016), I examine the extent to which the flow of influence and innovation between commercial and political marketers may be bidirectional and therefore could be seen as indicative of a two-way street with bidirectional interplay between commercial and political marketers rather than as a one-way street with one-way traffic from commercial to political marketers. The example I use to investigate this subject is tribal marketing.

An essential element of the contemporary play between political marketing and commercial marketing relates to tribal marketing. With that in mind, I use the results from thirtythree in-depth elite interviews with political marketers, market researchers, political researchers, pollsters and commercial marketers from Canada and the United States to examine the penetration of tribal marketing in both the commercial marketing and political marketing realms. Consequently, I ask the following research question: what is the relationship between commercial marketers and political marketers and the practice of tribal marketing? And, with that research question in mind, I hypothesize that tribal marketing is becoming a more recognizable, commonplace and effective way of marketing, and political marketers are more familiar with this practice and are better at building and mobilizing tribes than are commercial marketers. Yet we cannot realistically begin the process of answering this research question and testing this hypothesis without first knowing where the existing scholarly literature on the subject of the flow 
of influence and innovation between commercial marketers and political marketers and tribal marketing therein stands.

\section{Literature Review}

A crucial element of the contemporary play between political marketing and commercial marketing relates to brand neutrality or, more accurately, to a lack thereof. Neutrality has never been a prerequisite for successful political campaigning. In fact, quite the opposite is true. Politicians and the political parties to which they are conjoined are expected to stand for something and are expected to have policy positions on most issues of the day. In Churchill's Wit: The Definitive Collection (2009), it is noted how, in 1902, Winston Churchill pithily remarked: “"[A politician] is asked to stand, he wants to sit and he is expected to lie"' (p. 168). Cynical though it may be, few would deny that statement. But what about commercial marketing and the brands it promotes?

Douglas Atkin (2004) sets the stage for answering this question by stating that, "One of the greatest dreads of marketers is turning off any potential customers" (p. 17). Commercial marketers and the brands they promote have been engaged in a long-standing game of tug of war when it comes to the matter of neutrality. At issue has been the fear of offending, thereby likely losing a potential customer (Atkin, 2004; Scammell, 2015; Veroni, 2014). A great deal of consumer marketing has reflected this tendency and has subsequently resulted in insipid marketing to say the very least. The result is that, "trying to avoid any sort of negative impression frequently results in marketing that avoids leaving any impression at all" (Veroni, 2014, p. 63). As Atkin (2004) puts it in a more vivid fashion: "In the attempt to please everyone and offend no one most of the ideas [put forth by marketers] were compromised, their destiny to be relegated to dusty laminated sheets on cubicle walls and the old coffee mug in the company kitchen" (p. 24). 
The point being made here is that, with very few exceptions, commercial marketers have generally striven to attract the median or average consumer by way of inoffensive marketing campaigns, strategies, and tactics that are increasingly falling upon deaf ears (Atkin, 2004; Cova \& Cova, 2002; Veroni, 2014). They do so for a reason. With the escalating abundance of information provided by media via the many platforms that are frequently consulted on a daily basis, and with the general tendency to gravitate towards information that the user already finds appealing (thus sidelining unappealing information), there are fewer and fewer "average consumers" to cater to.

In the not-so-distant past, the key to creating effective marketing was tailoring your pitch to the middle of the bell curve of public opinion on any given matter (Atkin, 2004; Veroni, 2014). According to Veroni (2014), "Riding that curve is the focus of most marketing efforts. The goal is to make that bulge as high and as wide as possible, with the aim of achieving the highest common denominator" (p. 21). Unfortunately, the "highest common denominator" no longer lives up to its namesake for the simple reason that, "this focus on the middle of the curve results in a narrowing of vision. It ignores what's happening at the outer edges. And it's there, on the fringes, where passion lies. And it's passion that can make or break a brand" (p. 21). With a bit of elbow grease, and their near evangelical passion, "a small group of ardent believers at the tapering end of the bell curve can influence what the entire rest of the group thinks and does" (p. 21).

Those small groups of "ardent believers" have come to be known as "consumer tribes" or, if we are using the language of politics, one's "base of supporters" (Cova, Kozinets, \& Shankar, 2007; Chua, 2018; Goldberg, 2018; Sharkey, 2012; Veroni, 2014). But what exactly are consumer tribes, and how are they related to the potential bidirectional flow of influence between commercial marketing and political marketing? To begin to formulate an answer to that double-barreled 
question requires acknowledging a philosophical truth that helps us to understand and to frame our discussion of consumer tribes and tribal marketing. That truth is expressed by Bernard Cova, Robert V. Kozinets, and Avi Shankar (2007) when they state that: "Social life is a rich, complex, kaleidoscopic confusion that cannot ever be represented by 'causes' and 'effects"' (p. 5). However, it is more complicated than that. In essence, the aforementioned middle of the bell curve (a.k.a. the average or median consumer) is shrinking in terms of size and energy. This is further complicated by the fact that "Today's consumers are not in the market because they want to feel that they are buying something mass produced, confirming conformist longing, commercial" (p. 22). They are seeking the benefits of group identity that come with its exclusivity and cohesion, but are reframing that group identity on their own terms in a manner that, somewhat counterintuitively, is predicated on notions of uniqueness and individualism (Chua 2018; Goldberg, 2018; Tett, 2015).

In essence, exclusivity, whether real or merely perceived, is the driving force of the state of marketing at the current moment in time - or at least it should be. In this vein, the argument could be made that this is simply a natural side effect of the decades-long trajectory that much of Western society has been on, a trajectory in which we have tended to foster the belief that uniqueness conquers all and that anything is achievable with the supposed power of positive thinking, thereby spawning a participation ribbon culture that has recently been intensified by the self-indulgence and navel gazing — not to mention ego boosting — and false intimacy provided by social media. As Bernard Cova and Veronique Cova (2002) aptly put it, "The process of narcissism, induced by the development and widespread use of computers in all aspects of human existence, seems to characterise [sic] our daily life" (p. 596). While this is outside the scope of this paper, it warrants further study elsewhere. 
To bring the discussion back to the matter at hand, Atkin (2004) reminds us that, "Habits are slow to change" (p. 57). Consequently, "the marketing community has only just heaved itself, reluctantly, away from the belief that its consumer is a mass and homogeneous market" (p. 57). And, in the process of doing so, "It's moved from the broadcast 'Yell and Sell' to the extreme opposite point of view—seeing its customers as isolated individuals to whom one conducts 'oneto-one marketing"” (p. 57-8). As a result, "The pendulum has swung too far and entirely missed an insight on how to market effectively" (p. 58). Today, knowing the ins and outs of consumer tribes and tribal marketing is an essential component in "marketing effectively." In a nutshell, consumer tribes and the tribal marketing that constructs such tribes hinge upon not mere exclusivity but the relationship between exclusivity and community (Busby \& Cronshaw, 2015; Cova \& Cova, 2002; Cova, Kozinets, \& Shankar, 2007). Or, as Robert Busby and Sue Cronshaw (2015) concisely put it, "Consumer tribe theory suggests that the most successful brands provide a foundation to community, they give consumers a voice and provide a sense of belonging that supports their identity" (p. 99). That "sense of belonging" is built upon two visceral instincts: passion and community. Veroni (2014) gives us an even clearer identification of the tenets of consumer tribes by explaining that,

In recent years there has been much talk in the marketing world about the growing power and presence of consumer 'tribes.' The term refers to the idea that consumers tend to cluster around common needs and desires, and want to connect with others who are like them. Brands that help them make this connection, and that can lead the tribe, will be more successful. (p. 50)

Cova and Cova (2002) clarify the fact that, "the common denominator of postmodern tribes [such as consumer tribes] is the community of emotion or passion" (p. 598). It is the community of emotion or passion that tribe members feel for the product in question which creates the aura of exclusivity amongst the tribe's members and which ultimately comes to define the product itself 
(Cova \& Cova, 2002; Scammell, 2007; Scammell, 2015; Veroni, 2014). The community of emotion or passion that accompanies those in a tribe is not individualistic; it is shared amongst tribe members and crafted via the symbolism that is tied to the product itself (Cova \& Cova, 2002; Ostergaard \& Jantzen, 2000).

In this sense, tribal marketing could be viewed as the natural progression of recent thinking which holds that emotions are more significant in either making or breaking political campaigns than are pragmatic choices or considerations which affect voters personally, or political platforms that offer a wide variety of promised transactional outcomes (Butler \& Harris, 2009; Keller, 2002; Scammell, 2015; Westen, 2007). To capture the essence of this dynamic, in speaking about Drew Westen's (2007) influential book entitled, The Political Brain: The Role of Emotion in Deciding the Fate of the Nation, Patrick Butler and Phil Harris (2009) state that, "successful campaigns compete in the marketplace of emotions rather than in the marketplace of ideas" (p. 155). In that book, Westen (2007) himself sums up the role of emotion in contemporary politics by simply stating that, "The political brain is an emotional brain [emphasis in original]. It is not a dispassionate calculating machine, objectively searching for the right facts, figures, and policies to make a reasoned decision" (p. xv). Writing ten years after the release of The Political Brain, Michael Serazio (2017) echoes Westen's (2007) thinking by noting that, "Indeed, emotion, rather than reason, represents the essence $[\ldots]$ and the central orientation within branding a political candidate as a cultural product" (Serazio, 2017, p. 234). There is no disputing that the practice of tribal marketing recognizes and subscribes to this line of reasoning.

Related to emotion and passion is authenticity. Speaking about "cult brands," which operate by the same logic as consumer tribes, Atkin (2004) notes that authenticity is crucial in contemporary marketing and, more specifically, in the task of branding. He even goes so far as to 
say that "You cannot get [...] sustained buy-in if there is a whiff of inauthenticity" (p. 171). Channeling Douglas Holt (2002), Serazio (2017) explains how authenticity fits into the equation when he states that, "To achieve this authenticity [...] the brand has to seem 'disinterested' in the 'commercial intent' that is its ultimate reason for existence and furnish itself, rather, as the resource needed to enable production of the consumer's self" (p. 227). Put differently, the brand needs to offer the consumer something more than just its mere use value. With that in mind, "weightlessness" is becoming increasingly relevant in branding, be it for the commercial or political realm (Klein, 2000; Serazio, 2017). For example,

Just as corporations have sought to make themselves organizationally 'weightless,' by detaching from the manufacture of goods on balance sheets in favor of a less tangible, but more profitable brand meaning (Klein, 2000), so, too, is branded politics an effort to make the candidate 'weightless' - detached from the manufacture of policies in their media and advertising representations in favor of a more persuasive cultural meaning. (p. 234)

Regardless of whether or not that desired weightlessness is actually achieved, of vital concern in tribal marketing is cohesion (Chua, 2018; Cova \& Cova, 2002; Goldberg, 2018; Ostergaard \& Jantzen, 2000; Muniz \& O’Guinn, 2001; Veroni, 2014). Tribal marketing “supports products and services that hold people together as a group of enthusiasts or devotees" (Cova \& Cova, 2002, p. 603). And when trying to enhance the sense of cohesion within a tribe by stoking the aforementioned emotion and passion of its members and their devotion to the product or service being marketed, "linking value" is of great importance (p. 603). When speaking about linking value, what is at stake is 'the product's, or service's, contribution to establishing and/or reinforcing bonds between individuals" (p. 603). When speaking about tribal marketing, as when speaking about most things in life, the less-is-more approach does not apply since, "The greater the contribution of a product or service to the development and strengthening of the tribal bond, the greater its linking value will be" (p. 603). 
Unfortunately, there is a catch: linking value is difficult to manufacture and it is often separate from the "use value" of the product or service itself (Cova \& Cova, 2002, p. 603). In other words, that all-important linking value is usually created not by the product itself nor by its marketers, but instead by its consumers. The product may be consumed in the manner envisioned by the producer of the product or service, or be appropriated in a manner that is anything but what the producer of the product or service envisioned (Cova \& Cova, 2002; Scammell, 2007; Scammell, 2015; Veroni, 2014). To express the drawback of linking value a bit differently: tribal marketing, and the linking value that it relies upon, requires the consumers of a product or service to acquire a substantial sense of agency to communally define the brand image, functionality, and values of the product or service in question (Atkin, 2004; Cova \& Cova, 2002; Scammell, 2007; Veroni, 2014). Furthermore, as Atkin (2004) reminds us: "Ownership of the brand must be shared with its membership for it to thrive" (p. 188). But what is a "brand" and what do brands do? Scammell (2007) helps us fill in the blanks. She does so by explaining that, "In marketing, a brand is defined as 'the psychological representation' of a product or organization: its symbolic rather than tangible use-value" (p. 177).

Not surprisingly, consumer agency with respect to defining a brand's image is not the most appealing proposition for many brands and the advertisers that they rely upon in the attempt to craft and control their image in the eye of the public (Scammell, 2007; Veroni, 2014). The reason for this is that allowing the consumer to assume a role in defining a brand's image or meaning is a risky endeavour since it represents a loss of control from the perspective of the brand itself and the marketers or advertisers of that brand (Atkin, 2004; Scammell, 2015; Veroni, 2014). Yet, today, the argument could be made that it is an even riskier endeavour to try to retain every last ounce of control in crafting and maintaining a brand's image and that the process would likely 
prove to be little more than an exercise in futility anyway (Atkin, 2004; Veroni, 2014). For example, as Veroni (2014) aptly explains, "Just as the Internet and social media have ushered out the age of mass marketing, they have also shown the door to the age of centralized brand control" (p. 125). In other words, at the risk of sounding like a technological determinist, relatively recent developments in technology have already altered, and will continue to alter more systemically, the standard operating procedures of marketing and the craft of advertising.

Some have classified the current break with the status quo by labeling it the "Postadvertising Age" (Ries \& Ries, 2002; Scammell, 2007), a perspective which entails that "Advertising cannot substitute for the longer-term, more wide-ranging creation of reputation through sustained public relations" (Scammell, 2007, p. 178). Others, the most noteworthy of whom would be Veroni (2014), have labeled it the "End of Mass Marketing" which maintains that the old rules of marketing (i.e. the tailoring of a pitch to the middle of the bell curve that represented the median consumer) no longer apply since, "Today $[\ldots]$ content $[\ldots]$ is consumable in an infinite variety of ways. Information flow used to be determined by the media outlet; now it's determined by the media consumer" (p. 16). Typically, this means that a brand and its image - whether at the moment of conception or through the continuing process of brand maintenance - is a process that is negotiated between the producer and the consumer. It is in this environment that the agency of the consumer has increased exponentially, leading to a situation wherein "the challenge is how to tap into the creativity of others [i.e. consumers] to help promote the brand while still maintaining sufficient control, because full control is no longer an option" (p. 125-6). And this logic has come to be called "Open Branding" (Mooney \& Rollins, 2008; Veroni, 2014) or "User Generated Branding” (Arnhold, 2010). 
An important caveat must be mentioned at this point. Open branding may require a loosening of control of a brand and its image by the traditional brand image cultivators (the product itself and the marketers of it), but it does not require granting the consumer full agency in such matters (Arnhold, 2010; Mooney \& Rollins, 2008; Veroni, 2014). To claim otherwise would be unrealistic and naïve. In light of that fact, Veroni (2014) reminds us that, "Open branding is not about letting go completely; it's about understanding that others will inevitably have their say" (p. 126). And when it comes to letting others have their say, "Rather than trying to silence those other voices, marketers must find ways to ensure that those outsiders are singing in harmony with the brand and not creating discord" (p. 126). That is a difficult task. Still, as difficult and unnatural as that task may be, its necessity has been recognized by political marketers for quite some time (Veroni, 2014). The reason for this is inherently tied to the fact that open branding and tribal marketing go hand in hand. That notion was alluded to earlier by referencing how, for any given consumer tribe to remain vibrant, the consumers therein should be active participants in the creation of the meaning of the tribe and the brand that it coalesces around (Atkin, 2004; Cova \& Cova, 2002; Cova, Kozinets, \& Shankar, 2007; Veroni, 2014).

Veroni (2014) notes that, "Smart marketers, like smart political strategists, understand that avoiding consumer anger and controversy is increasingly difficult. The trick is not to attempt to dodge it but to learn how to manage it and turn it to your advantage" (p. 50). In other words, marketing effectively in our current landscape, which is increasingly populated by various competing consumer tribes, requires applying the logic and "lessons of wedge politics" to the practice of commercial marketing (p. 50). Thus, the mantra of wedge politics that you should "say or do something that appeals to your base of supporters [i.e. your tribe], even though you know it will antagonize others" represents an important consideration and tactic to be used in our 
increasingly fragmented marketing landscape (p. 54). Based upon this logic, "Smart marketers will understand that using the anger of some will allow them to win the support of others," thereby growing the size of one's tribe and also its energy and passion (p. 54). But Atkin (2004) reminds us that this is a fine line to walk since, "Difference is a fickle beast" (p. 158). This is because, to be successful, cult brands (a.k.a. consumer tribes) need to be "able to artfully manipulate the tension dial to be different enough, but appear similar enough [emphasis in original]" (p. 160). As was referenced earlier, they need to offend the wrong people to attract the right people to their brand or cause.

Furthermore, when it comes to branding, "the minute you create a tribe, with its internal cohesion, you are by default creating an opposing tribe, with its attendant conflict" (Veroni, 2014, p. 51). With that in mind, Amy Chua (2018) offers an important philosophical reminder: "Humans are tribal. We need to belong to groups $[\ldots]$ but the tribal instinct is not just an instinct to belong. It is also an instinct to exclude" (p. 1). In her words, tribalism "creates a virtuous Us [those in one's tribe] and a demonized Them [those outside of one's tribe]" (p. 203). In his jeremiad entitled Suicide of the West: How the Rebirth of Tribalism, Populism, Nationalism, and Identity Politics is Destroying American Democracy (2018), Jonah Goldberg also notes this dark side of tribalism by simply stating that "Americans [are] break[ing] up into 'tribal' coalitions against other Americans they only see as the 'other'” (p. 43). Political marketers are aware of these patterns. That being the case,

This is where political strategists depart from [commercial] marketers. While the [commercial] marketer is focusing all of his or her attention on the internal workings of the tribe, trying to understand its every characteristic and nuance, the political operative recognizes that it's equally important to understand the opposing tribe. It is the tension that exists between tribes that, to the politician, can be a source of tremendous power and leverage. (p. 52) 
Political marketers have long been successful at developing consumer tribes, knowing what makes opposing tribes tick and then tailoring their messaging accordingly to either bolster the support of one's own tribe or, conversely, to attempt to siphon support away from members of opposing tribes. This thinking is now permeating the practice of commercial marketing. That permeation is occurring precisely because, "these days, in virtually every consumer arena, people are splintering into tribal groups and demanding to know where the brands they purchase stand on any number of issues" that extend beyond the scope of the use value of the product itself (p. 50).

\section{Findings \& Results}

To gauge the respondents' thoughts on the increasingly topical but controversial subject of tribal marketing, a two-part question was posed. The first part of that question asked: What comes to mind when you hear the term "consumer tribe" or "brand tribe?" If something came to mind, the second part of that question was then asked: Do you think that there's a similarity between how that term is interpreted in the commercial context versus the political context? Needless to say, if nothing came to mind when the first part of the question was asked, the second part was not asked. Perhaps unsurprisingly, the diverse cross-section of interviewees resulted in a wide range of opinions on the topic of tribal marketing. Accordingly, for both organizational and logical reasons, we will examine the first part of the two-part question prior to the second.

While a number of interviewees were unfamiliar with the terms consumer tribe or brand tribe, or with the notion of tribal marketing in general, most had some familiarity with the broader concept itself. Nonetheless, the varied professional and geographic backgrounds of the interviewees ensured a wide array of diverse opinions and perspectives on the subject matter. Some, like Interviewee \#24, express a hint of cynicism when discussing the topic. For example, when asked the initial question about tribal marketing, he responds, "I don't really know. I mean I 
think that's kind of like a buzzword" (Interviewee \#24, personal communication, December $27^{\text {th }}$, 2019). He contextualizes his response by adding that,

Now keep in mind, as a pollster, I always want to put people in a box so [...] as people, right, I mean it's human nature for us to want to put people in a box, right? So, if I can easily, say, put you in one place and put your neighbor in another place, it's great. But I think that's just kind of a buzzword. (Interviewee \#24, personal communication, December $\left.27^{\text {th }}, 2019\right)$

By wanting to "put people in a box" as a pollster, Interviewee \#24 is referring to the all-important task of quantifying individuals for the purpose of crafting surgical microtargeting voter outreach strategies.

Interviewee \#9 also cynically colors his initial thoughts on tribal marketing, as is evinced when he states that the first thing that comes to mind "would be trying to sell books. Or, I guess, Ted Talks these days, or podcasts" (Interviewee \#9, personal communication, October $30^{\text {th }}, 2018$ ). But he is quick to transition from cynicism to historical contextualization when he explains that,

You can call it whatever you want, be it a tribe, because that suggests there are, you know, different behaviors that are unique to that body that you want to be aware of if you're communicating with them or trying to move them. But, yeah, there's always been descriptions, and the lairing of the description and the word used to capture those descriptions depends on who's writing them and how they're seeing people organize. So, it's [...] yes, I've heard those terms, or versions of those terms for years [emphasis in original]. And people have always looked to people in collectives. So, that's just the term of the days, I suspect. (Interviewee $\# 9$, personal communication, October $30^{\text {th }}, 2018$ )

In other words, from his vantage point, the terms may change but the tactics remain the same.

Interviewee \#22 also sees the label of tribal marketing as a new term for an old tactic when he notes that, "I think that that's kind of another kind of way of companies using the concept of like, a customer persona, or it's kind of like their target markets for like an old-fashioned word would be that" (Interviewee \#22, personal communication, November $27^{\text {th }}, 2018$ ). With this in mind, he adds that, "I think it's [tribal marketing] a different way of visualizing that" (Interviewee \#22, personal communication, November $27^{\text {th }}, 2018$ ). 
Similar to both Interviewee \#24 and Interviewee \#9, Interviewee \#26 also frames his initial thoughts about tribal marketing in a cynical fashion. For example, "So my first thought, what comes to mind, is I think it's a dumb term" (Interviewee \#26, personal communication, January $\left.23^{\text {rd }}, 2019\right)$. Yet, he too pivots from this perspective when he fleshes out his thinking:

But outside of that, I think about data and how data is used to divide people into various tribal categories. And I think it's more a symptom of the use of data rather than [...the] very few people [who] would consider themselves [...] maybe in their cars, they're tribalaligned. But in politics, there are people that call themselves Progressives, or people that call themselves Democrats, and I suppose you could look at them as tribal in that sense. But I don't really ever hear people using those terms in politics as much. (Interviewee \#26, personal communication, January $23^{\text {rd }}, 2019$ )

But not every interviewee who had heard of tribal marketing, brand tribes or consumer tribes thought that those terms were generally not utilized by political practitioners. Interviewee \#11 is one such individual who holds that contrasting view. For example, he recounts that, "up in Ottawa, when I was there — and people use that term down here [in Toronto] too — but [...] people from other political parties [would] say [...] 'But do people in your tribe do X, Y, or Z?'” (Interviewee \#11, personal communication, October $\left.31^{\text {st }}, 2018\right)$. With that established, we can backtrack and unpack his thoughts on what tribal marketing means to him. He offers a terse definition when he states that, "Well, that's the group of people who are loyal to a particular brand or party $[\ldots]$ it's the grouping of loyal supporters" (Interviewee \#11, personal communication, October 31 ${ }^{\text {st }}, 2018$ ).

Interviewee \#15, a Senior Consultant at a Canadian government relations, public affairs and opinion research firm, and the former Director of Market Research in the Prime Minister's Office (PMO), offers a similar definition, both in terms of content and language use, when she notes that, for her, a consumer tribe or a brand tribe constitutes "A group of people who have a loyalty $[\ldots]$ as well as $[\ldots]$ a tendency to either purchase or vote a certain way" (Interviewee \#15, personal communication, November $\left.7^{\text {th }}, 2018\right)$. Loyalty is also an essential ingredient for tribal 
marketing according to Interviewee $\# 6$, as is evident when he defines the term in the following manner:

People who have a loyalty with a particular brand and they always buy it, because they've always bought it - and, you know, and I can personally probably think of a number of brands that I always flock to even though I don't really think about it, or know why. But, yeah, that's what I would think of. (Interviewee \#6, personal communication, October $17^{\text {th }}$, 2018)

Interviewee \#28 also considers the importance of loyalty in establishing his thoughts on the practice of tribal marketing. For instance, he claims that, "what comes to mind would be people who are loyal to a specific group $[\ldots]$ or have a shared quality and you're trying to have your marketing resonate towards that cohort and also influence each other inside of that group" (Interviewee \#28, personal communication, January $\left.28^{\text {th }}, 2019\right)$. Here, Interviewee \#28 makes the important point that, as far as he is concerned, tribal marketing is not solely defined by a sense of loyalty. It is also defined by influence between marketer and consumer on the one hand, and consumer and consumer (a.k.a. relationship marketing) on the other hand. Put differently, for him as a marketer, you want members of your tribe to organically recruit their peers into your tribe on an ongoing basis.

This line of reasoning is incorporated into Interviewee $\# 8$ 's thoughts on tribal marketing as well, as can be seen when he remarks: "Well, that implies a cohort of consumers who coalesce around (from an attitudinal perspective and preference perspective) who coalesce around a certain brand that they are favorable towards, and likely are promoters or proselytizers [of]" (Interviewee $\# 8$, personal communication, October $\left.26^{\text {th }}, 2018\right)$. He elaborates on his thinking by explaining that, Well, not a formal brand ambassador [...] but a brand tribe to me is the equivalent of super fans. And, they're worth their weight in gold, because they will disseminate typically positive messages and perspectives on a given brand, because they really believe in it. It's authentic. Yeah. And real. (Interviewee \#8, personal communication, October $26^{\text {th }}, 2018$ ) 
But, as will be discussed a little later in this section when comparing how tribal marketing is envisioned in the commercial marketing versus the political marketing context, there is a dark side to the notions of authenticity that tribal marketing can foster among individuals. And, because notions of authenticity, loyalty, and organic relationship marketing associated with effective tribal marketing can be extremely strong, as Interviewee \#21 reminds us, "I think every commercial marketer wants to create that tribe. That's why they all have their charitable giving arms or various non-profit wings, whatever corporate social responsibility" (Interviewee \#21, personal communication, November $23^{\text {rd }}, 2018$ ). That said, he is quick to point out that not all such efforts are equal in their depth and breadth, which can be seen clearly when he reasons that, "I think a lot of that $[\ldots]$ I think a lot of that is the feel-good stuff. I don't mean to disparage the commitment. But I don't think Pepsi or Coke are building a tribe like Beto O'Rourke is" (Interviewee \#21, personal communication, November $\left.23^{\text {rd }}, 2018\right)$. Even so, he notes that,

I think that there are progressive brands that are. And they're brands that $[\ldots]$ it kind of gets back to that whole thing I said earlier about the generational evolution of consumer market or consumer purchasing habits [...which, for example] is, look at these products that are helping you save energy in your home. So, you're protecting the environment, whether it's a Nest [thermostat] to manage your home temperature when you're not there. I don't think Nest creates a tribe. But that kind of smart home [...] in the smart home marketplace that is creating energy efficiency, I think that's a tribal vertical market. (Interviewee \#21, personal communication, November $23^{\text {rd }}, 2018$ ).

A key phrase that Interviewee \#21 mentions here, "generational evolution of consumer market or consumer purchasing habits" warrants further consideration when unpacking the interviewees' initial thoughts on the subject of tribal marketing. Interviewee \#13 injects an important thought into that discussion when she reminds us that, "it's not just about marketing. It's also about reaching people the way they communicate and digest and ingest information now" (Interviewee \#13, personal communication, November $7^{\text {th }}, 2018$ ). She adds more to her thinking in explaining that, "People aren't getting information the same way they used to. And, so, you 
need to adapt to get your message out" (Interviewee \#13, personal communication, November $7^{\text {th }}$, 2018). Interviewee $\# 14$ echoes this sentiment and highlights just how quickly the political marketing landscape shifts when he notes that, "I think we should also not probably lose sight of the fact that there's no stability in this. Like, and not much history. So, the way people communicate now is ridiculously different from like two elections ago" (Interviewee \#14, personal communication, November $\left.7^{\text {th }}, 2018\right)$. And, not all age groups communicate in the same fashion. With this in mind, Interviewee \#31 posits that,

Well, I mean, that's [tribal marketing] really just adjusting and crafting your messages to be audience specific. It's about being culturally competent. So, if you want to talk to a group of 18-to-25-year-olds, you're probably going to talk to them about an issue in language both visual and written or oral that is going to be different somehow than the language, visual, oral, or written that you're communicating with people who are 55 to 60 . (Interviewee \#31, personal communication, January $30^{\text {th }}, 2019$ )

Interviewee \#27 sees eye to eye with Interviewee \#31 on the topic of tribal marketing, as is

clearly evinced when he offers us his thoughts on the term:

Okay, here's tribal marketing: Candidate $X$ figures out, midway through a campaign, that the people most receptive to her message are people who are between the ages of 18 and 32 who are single. Okay, now we know in this demographic that, for whatever reason, we're doing really well with that group, and that we can isolate that group on Facebook or some other social media, but we know where they are, or we know what their interests are, or we know how to get on their news feed, "So let us spread the word to people who may not yet be registered to vote but still can register to vote, that she is extremely popular with this group and why so that we can goad them into voting." (Interviewee \#27, personal communication, January $24^{\text {th }}, 2019$ )

As was just referenced by Interviewee \#14, Interviewee \#27 also thinks that the tectonic electoral plates that tribal marketing stands upon have shifted drastically in a very short amount of time, as is clear when he remarks that,

This is a recent phenomenon in the United States, but in the mid-term elections in 2018 , voter turnout was up 30 and $40 \%$ in a lot of places, and a lot of those people had never voted before. A lot of those people may have only voted once in the past 10 years in primaries, but they were motivated to do so by this tribal networking that goes on, which is very easy to do with Facebook. Yeah. If you ask me how to do tribal marketing of 
Wrigley Spearmint Gum, I would say, "You need to talk to somebody else. I don't know." But I'm sure they know who it is and however they define it $[. .$.$] I'm sure the people at$ Wrigley's know who likes their gum. (Interviewee \#27, personal communication, January $24^{\text {th }}, 2019$ )

Just as important as recognizing the fact that the electoral landscape is quickly and continually changing, and that these changes tend to foster tribal marketing, numerous interviewees in this sample thought that data-based microtargeting (or segmentation) and tribal marketing go hand in hand, with some even going so far as to say that such targeting practices promote tribal marketing - for better or for worse. Interviewee \#2 begins that discussion for us when he states that, "Oh (laughs), Consumer Tribe? I assume that's [...] I assume that's some kind of segmentation of consumers by either a combination of attitudinal demographic data or some other form that would mean they are like-minded in some way" (Interviewee \#2, personal communication, September $\left.24^{\text {th }}, 2018\right)$. When it comes to tribal marketing, segmentation is also on the mind of Interviewee \#32, as is undeniably witnessed when he is asked What comes to mind when you hear the term "consumer tribe" or "brand tribe?" and he promptly and unequivocally responds: "Well, segmentation, basically" (Interviewee \#32, personal communication, January $\left.31^{\text {st }}, 2019\right)$. He offers more insight into his thinking when he explains that, for him, tribal marketing entails

Doing something that's going to appeal to that specific tribe or, well, demographics aren't quite the right word, because, often, it's attitudes and values - not just your demographics. But, yeah, you know $[\ldots]$ segmentation is effectively what comes to mind there. And trying to get your product, or service, or company, identified with that tribe. (Interviewee \#32, personal communication, January $31^{\text {st }}, 2019$ )

Interviewee $\# 5$ examines the matter at hand from a more hypothetical perspective, but ultimately arrives at the same conclusion. For instance, he states that, "You know, it's [...] it's obviously about building a[n] understanding [of] behavior into groups. That people who $[\ldots]$ people who, you know, shop at one store, buy one sort of thing are likely to buy another sort of thing" 
(Interviewee \#5, personal communication, October $12^{\text {th }}, 2018$ ). He then makes an important point that, in his opinion, the expectations of tribal marketing and the realities of it may not be perfectly aligned. Or, as he puts it himself:

From a marketing perspective, the Holy Grail is to be able to market to people individually [...] That's the dream; whether it's political or commercial. The [...] reality is that, in most cases, the goal is to group people into tribes, or groups, or whatever you want to call them, "segments" (and how many you have depends on the quality of your data), and then you market to that segment. So, again, you know, [...] it's better to market to a segment that you know [...] you divide everybody into four segments and it's better [...] you'll have better success marketing slightly different products or messages to each of those four segments than just treating everybody exactly the same. But it's better to have 400 segments than 4. (Interviewee $\# 5$, personal communication, October $12^{\text {th }}, 2018$ )

In essence, the less is more approach does not apply when it comes to the microtargeting (or segmentation) that effective tribal marketing strategies rely upon.

Interviewee \#30 also sees tribal marketing through the lens of microtargeting which he refers to a "clustering." For example, he reasons that, "I mean, I think of that as [...] that's just a new name for clustering. That's just a new name for getting people [...] for putting people into groups and trying to figure out how to best address those groups" (Interviewee \#30, personal communication, January $30^{\text {th }}, 2019$ ). A complimentary contextualization of tribal marketing is voiced by Interviewee \#25 when he states that,

I've heard [of ...] tribal marketing a little bit. Breaking large groups into manageable sizes. Yeah. So yeah. There's been a lot of breaking groups into different personas. That's a thing that people do a lot of. I use different personas for targeting all the time. (Interviewee \#25, personal communication, January $15^{\text {th }}, 2019$ )

But the "different personas" (to use the words of Interviewee \#25) or the different microtargeting or segmentation strategies that are increasing the appeal, presence, and penetration of tribal marketing do not come without consequences.

Interviewee \#3 commences the commentary upon some of these critical consequences when he states that, "We're writing a lot about that [tribal marketing] these days and it's really a 
reflection of the fact that the middle has dropped out of politics and people are more and more identified with, I would say, better defined types of positions" (Interviewee \#3, personal communication, October $\left.1^{\text {st }}, 2018\right)$. He paints a more detailed picture of how this is so when he explains that,

So, in the United States, it's a great way of looking at, you know, what a Democrat is today versus what a Republican is today. You know, all of the sort of images, signals, and the credibility of the spokespeople and all the rest of it is very differentiated. And it's not quite that way in Canada, but it's moving that way. (Interviewee \#3, personal communication, October $1^{\text {st }}, 2018$ )

A more pessimistic perspective is voiced by Interviewee \#14 when he notes that,

Well, the use of the term tribe, I think of more politically. And, it's a really dark term, in my view now, because $[\ldots$. because tribes tend to involve people doing things out of a sense of loyalty and emotional commitment that sometimes go against what your rational or moral compass would normally tell you to do. (Interviewee \#14, personal communication, November $7^{\text {th }}, 2018$ ).

He elaborates on his position when he argues that,

Like, there's no point in having tribal loyalty if you're not going to ask people to do something they're uncomfortable with. [It's] more the [...] emotional brain that, you know, you can develop and leverage [with] a tribe, and exploit it, or serve it, or both. But when you create a tribe, the idea of tribalism is: "I'm in this one, not that one; that one is not us." And that is divisive by nature and problematic in politics. (Interviewee \#14, personal communication, November $7^{\text {th }}, 2018$ ).

And, with this in mind, he reveals what he envisions as the logical conclusion for the kind of

"emotional brain" appeals that tribal marketing fosters when he explains that,

So, what's happening a lot with tribal behavior in politics is [...] that people now end up instead of picking a tribe that fits their values and aims, they end up shaping their values and aims as a result of the tribe they're in. Like, "If that's what the tribe needs me to say, that climate change isn't really happening, well, fuck that, climate change isn't really happening." Right? And then, as soon as that leader says, "Actually, we do believe in climate change," well then everybody in that tribe is like, "Yeah. We've always fuckin" believed in climate change. We've always just thought these solutions were wacky." What the fuck? That's Orwellian! Yeah. That's why I think of tribes being really unhelpful. (Interviewee \#14, personal communication, November $7^{\text {th }}, 2018$ ) 
Orwellian or not, tribal marketing is becoming a more recognizable, commonplace, and effective way of marketing. Interviewee $\# 13$ is clearly in agreement as is evident when she states that, "I think tribes are incredibly important in marketing. And I think that that tactic or logic is incredibly persuasive" (Interviewee \#13, personal communication, November $7^{\text {th }}, 2018$ ). Looking back at the recent past, she remarks that, "From [the] political context, it's how Trump won. He knew how to mobilize his tribe" (Interviewee \#13, personal communication, November $7^{\text {th }}, 2018$ ). Interestingly, Interviewee $\# 13$ offers a dose of self-reflexivity when she admits that,

From a marketing perspective, I totally ascribe to tribes, and I know I'm influenced by them, so, if for your purposes, it is still separate from our emotional feelings to the word, to a connection to the word, it is incredibly important and powerful and it works. I would not diminish the power of that rallying. (Interviewee \#13, personal communication, November $7^{\text {th }}, 2018$ )

Like others in this study, she points out that, "It does have a negative, it can have a negative connotation" (Interviewee \#13, personal communication, November $7^{\text {th }}, 2018$ ). Interviewee $\# 4$ proceeds to illuminate why that negative connotation exists:

Well, [...] it relates to the same idea, right? [i.e. Consumer Tribe and Brand Tribe] That we've... and, I think, you know, here's where it's disturbing to me: it's that, where we take the idea of pride, then we've given away rationality. Right? Because we're not interested in having a discussion and learning anything more; we're interested in who's wearing a red jersey and who's wearing a blue jersey an who's wearing an orange jersey. That's it. There's nothing more to it. It's tribal. It's tribal. It's about identity. (Interviewee \#4, personal communication, October $11^{\text {th }}, 2018$ )

Be that as it may, Interviewee \#13 notes that, "But, it's not all negative for me. For me, it means similarities, rallying and the like, you know, having a shared something with someone else. You know, it could be commercial, it could be politics, it could be whatever" (Interviewee \#13, personal communication, November $\left.7^{\text {th }}, 2018\right)$.

With the respondents' initial thoughts on tribal marketing examined, we can now turn our attention to the second part of the interview question aimed at that particular matter which asked: 
Do you think that there's a similarity between how that term is interpreted in the commercial context versus the political context? Interviewee $\# 15$ offers a point of entry into the variety of answers provided by the respondents on this subject when she argues that,

I think there are probably some broad similarities. Well, they're probably measured in somewhat the same way. But I imagine the political one is much deeper and likely a lot more [...] I mean, do you have an affiliation or a brand tribe to a bar of soap? I imagine who you're voting for is a lot more fundamental to who you are as a person. (Interviewee $\# 15$, personal communication, November $7^{\text {th }}, 2018$ )

Interviewee $\# 3$ has a similar position on the topic of tribal marketing, as is shown when he explains that, "I think what's happening is that the tribalism is much better reflected in the world of politics than it is in the world of commercial activities. But, increasingly, the political is seeping into the commercial" (Interviewee \#3, personal communication, October $1^{\text {st }}, 2018$ ). He then provides us with a couple of interesting examples of this overlap:

Take a look at the new Nike advertising campaign [the Colin Kaepernick campaign]. Or take a look at, when it's done poorly, what Pepsi tried to do with one of the Jenners, with her street protest advertisement. Yeah. So, most of the emotions [...] the you know, the sort of big battles of the world are taking place around this idea of what is the say, for example, the American tribe? Or, you know, what is a real French person? Or a real Italian? Or a real Swede? What is that? What does it mean to be Swedish now? So, the tribalism is that sort of in and out kind of position. It's leaking into the commercial world because, increasingly, the products and services that you buy are a reflection of the tribe you're a member of. And you see some of that in Canada, right? So, Tim Hortons [...] Stephen Harper [...] would go to Tim Hortons [...] and would accuse everybody who went to Starbucks as being unCanadian. He never actually said that the signal was sent. That's the political leaking into the commercial, not so much the commercial leaking into the political. (Interviewee \#3, personal communication, October $1^{\text {st }}, 2018$ )

Here he illuminates the increasing overlap between the political and the commercial facets of life and also two recent and vivid examples of politically-charged advertising campaigns conducted by commercial marketers which broke the long-standing mold of politically neutral commercial marketing (Nike's Colin Kaepernick campaign and Pepsi's Kendall Jenner campaign). 
In the words of Interviewee \#4, "They seem to me kind of the same thing [tribal marketing in the commercial context as opposed to the political context]. It's kind of still an appeal to identity" (Interviewee \#4, personal communication, October 11 $1^{\text {th }}, 2018$ ). Furthermore, as he sees it,

It's self-affirmation in some way of it - whether it's because I'm driving a Ford, or because I'm voting Republican. It's not a rational [...] it's not like, here are the features and benefits of a Ford [...Or] here's the platform of Doug Ford - he didn't have a platform. [It's] more visceral. Yeah, it's about the identity thing, right? (Interviewee \#4, personal communication, October $11^{\text {th }}, 2018$ )

That "identity thing" is where tribal marketing thrives: in the visceral, the emotional, the unrelentingly human need to fit in somewhere and to be a part of something. With this in mind, a number of respondents likened tribal marketing to the intense bonding that is present among hardcore sports fans. And rightly so, because, as Interviewee \#33 says: "politics is a little like sports for the un-athletic" (Interviewee \#33, personal communication, February $4^{\text {th }}, 2019$ ). He expands upon this notion when he reasons that,

And so, you got your New England Patriots fans and you got your Los Angeles Rams fans, and they're Patriots fans all the time. But when something happens, you just spark them a little and they become rabid Patriots fans. So, the same thing with Democrats and Republicans and conservatives and liberals. They're always there, and if you can give them a reason to get excited - an interesting person to follow, an interesting issue to get fired up about - then you're just lighting that match and it's ready to go off. (Interviewee \#33, personal communication, February $4^{\text {th }}, 2019$ )

A complimentary contextualization of tribal marketing is voiced by Interviewee $\# 11$ when he puts it this way:

Certainly, sports teams come to mind. That level of relationship. Fans, which is why, you know, that's the term: fanatics. Fans are very tribe oriented. They behave in a certain way: they gather, they cheer, they go through experiences together, good times, bad times. (Interviewee \#11, personal communication, October $31^{\text {st }}, 2018$ )

That intense tribal marketing which is part and parcel of political marketing is increasingly appearing in the realm of commercial marketing as well. As Interviewee \#17 puts it himself: "Well, 
I mean certainly there's a little bit of tribalism in consumer marketing" (Interviewee \#17, personal communication, November $\left.12^{\text {th }}, 2018\right)$. Using an example, he then walks us through how he sees tribalism working in the commercial marketing world.

You know, there's a lot of people who were Nike or Adidas 'til they die, right? Or Xbox or PlayStation. And people will defend their brand. And, you know, I used to remember when the first ever Xbox came out, I remember being online and being excited to get one and people were just having these crazy [emphasis in original] online [discussions] about which one's better. It's like, neither of them is even out yet. You know? So, definitely, you know, it happens in the commercial world. But, it's nothing compared to political, right? Like, you've got people who have — quite frankly — no idea what they're talking about (laughs) so many times, and they will just [...] it's like a life or death thing, right? Like they will go to war for the side that they've picked. And, you know, I think we're seeing some of the worst of that in the United States right now. We're seeing the very negative things that can happen with that. So, you know, I would say political tribalism is mostly a negative thing. It's a lot worse than you would see in consumer commercial. (Interviewee $\# 17$, personal communication, November $12^{\text {th }}, 2018$ )

Why is this the case? As was hinted at earlier, the stakes are typically lower and emotions usually do not usually run as high when it's a matter of commercial brands as opposed to political brands (be they the parties or the individual politicians themselves). Interviewee \#16 is on the same page, as can be seen when he explains that,

Well, I mean, people in the commercial context talk about tribalism all the time, in the sense is that we're trying to find something, common values, common interests, shared interests that binds people together that we can use to create real strong engagement and then, ultimately, evangelicalism, where they can go out and brag about their adherence to Starbucks or whatever to their friends and try to widen the circle. I think tribalism in the political context has a different meaning. And it's gone to a fairly dark place in the last few years, in the sense that it's about polarity and it's about divisiveness and, you know, competing visions. I don't think that people who are tribal in the sense of, they really, really love Starbucks really, really hate people who go to Tim Hortons. It doesn't have the same connotations in the commercial context that I think it does in political. (Interviewee \#16, personal communication, November $8^{\text {th }}, 2018$ )

Returning to the crux of the latter part of the discussion on tribal marketing entails fleshing out whether or not the interviewees thought that that term is used in a similar fashion in both the commercial marketing and political marketing realms. Interviewee \#32 helps us navigate back 
towards such a discussion when he notes that, "I don't think they are interchangeable” (Interviewee \#32, personal communication, January $\left.31^{\text {st }}, 2019\right)$. He elaborates on his thinking by explaining that,

I think there's some common overlap[s], but I don't think that how you segment a commercial one of the tribes are necessarily the same for politics, because there can be brand loyalties and appeal that cross some political thresholds. Political tribes are probably a bit more $[\ldots]$ not permanent, but harder to dent. I don't think people change political tribes so much, but I think, [with] commercial tribes, people can change more often. (Interviewee \#32, personal communication, January 31 ${ }^{\text {st }}, 2019$ ).

He then walks us through a particularly Canadian example that exemplifies how commercial tribes

typically ebb and flow much more freely than do political tribes. For instance, he recounts how,

I mean, just as an example, I mean, if you look at most countries, unless they do really badly, most political parties keep 30 to $40 \%$ of the vote. Bad elections: 30 ; good elections: 40-45. The great thing I always recall was [...] was it twelve years ago? It might be longer now. Research in Motion (RIM), which manufactured the BlackBerry, and Apple had almost equal share prices. Today, Apple share prices are a hundred times the price of RIM. BlackBerry's [...] been destroyed. At the time [emphasis in original] when the BlackBerry was out, it had a tribe. It was business people. No [emphasis in original] business person $[\ldots]$ it was a sign that you were in business. People didn't have them just for fun. It was the sort of business sign, like a Rolex watch is for rich people. And, everyone had them. So, there was a very strong BlackBerry tribe. [Then] the iPhone came along and [...] everyone had an iPhone. Twelve-year-olds now get an iPhone. So, there's an example of how you can have massive change with your commercial tribes, but less-so with political tribes. Not totally. There are some political parties that do go extinct, but I do think that the history is that most political parties over 40 or 50 years have actually maintained reasonable levels of support within their terrain. (Interviewee \#32, personal communication, January $\left.31^{\text {st }}, 2019\right)$

Yet even though political tribes are generally more stable than their commercial counterparts, they face challenges that were not as acute even in the relatively recent past. Interviewee \#6 walks us through the challenges of the terrain faced by political marketers when attempting to craft and maintain their tribe(s) as he notes that, "And I think that parties are banking on it a lot. But it's increasingly difficult, because there used to be a lot more identification people 
had with parties" (Interviewee \#6, personal communication, October $17^{\text {th }}, 2018$ ). For example, as he explains it,

They were Liberals, they were Conservatives, and they always were. But you're seeing that really, really down in Canada, and you're seeing that in a couple of recent provincial elections [...] people who have voted for one party or another - for perhaps all of their lives - are now shopping around. So, that loyalty is even harder than [...] it is much harder to maintain than it used to be [here] in Canada. Whereas, in the United States, you still see, you know, partisanship is still very, very entrenched. Whereas here, here you wouldn't really think about it too much if your daughter or your son married someone who was from a different party. You wouldn't; it really wouldn't be something you'd think about too much. Whereas, in the United States, they've done polls on it and, you know, there's been people who say, you know, they would be upset if their child married a Republican or a Democrat - it's much further entrenched there than it is here. (Interviewee \#6, personal communication, October $17^{\text {th }}, 2018$ ).

Interviewee \#1 offers an important consideration for us by stating that, "I think [that] even though people are polarized, tribes will change, right? I think that there's less of a relationship in politics. There's less ownership. We expect less of them" (Interviewee \#1, personal communication, September $\left.12^{\text {th }}, 2018\right)$. Interestingly, Interviewee $\# 1$ also provides us with an opinion on the ebb and flow of tribal marketing that contradicts that just provided by Interviewee \#32 when he reasons that, "I think the cult of politics will shift more rapidly than the cult of products" (Interviewee \#1, personal communication, September 12 $\left.2^{\text {th }}, 2018\right)$.

Shifting from the matter of tribe stability back to whether or not tribal marketing is interchangeable between the commercial marketing and political marketing contexts, Interviewee \#8 argues that, "I would say they're probably pretty close to equivalent. Your party membership would be your brand tribe, in many respects [...] your campaign team, your workers, and yeah, elements of your base" (Interviewee \#8, personal communication, October $\left.30^{\text {th }}, 2019\right)$. Interviewee \#23 takes a different approach to this subject by beginning his response by way of an example, but arrives at the same conclusion, as is clear when he states that, when it comes to tribal marketing, 
“I think of Apple immediately" (Interviewee \#23, personal communication, December $5^{\text {th }}$, 2018).

He reveals his rationale by explaining that,

We have these brands, tribes where people become early adopters. Well, Apple is the easiest to kind of jump all over. And those early adopters become defining. And I think that in politics, it's a little bit different, in that it's simpler. I guess maybe it's the same. It's a simple metric that says this is who I belong to. This is what I am. (Interviewee \#23, personal communication, December $5^{\text {th }}, 2018$ )

However, he makes an important point when discussing such tribalism, that being that,

In corporate tribalism, you actually tend to know more. Whereas in political tribalism, you don't know very much. You know who your team is, right. So political tribalism has more to do with like cheering for a sports team than it does with, you know, my team's the Conservatives. Go Conservatives go. Whatever the Conservatives say, I believe in. And it's hard to move away from that tribalism, in the same way that, you know, the Flames scored nine goals, yeah, go Flames! (Interviewee \#23, personal communication, December $5^{\text {th }}, 2018$ )

Interviewee $\# 5$ also holds that tribal marketing is interpreted similarly between the commercial and political marketing contexts when he notes that, "I think it's called different things, but I think any political party that knows what they're doing has a very good understanding of who their target voters are and what the buttons to push on them are" (Interviewee \#5, personal communication, October $12^{\text {th }}, 2018$ ). Interviewee $\# 33$ concurs, arguing that pushing the buttons of tribe members can be an easily accomplished and immensely effective tactic:

Well, look, every brand would love to have a tribe. And it's a really difficult thing to do and I've heard people say tribal marketing, I heard people say spreaders of the Gospel of a particular brand, and Apple is a great example of that. Apple fan people and they love that brand, love, love, love it [emphasis in original] and then will buy practically anything they put out. So, any marketer would love to do that. Whereas in politics, it almost feels like it's a little easier to generate that. It's like, in other words, it's always just lying a couple of millimeters below the surface and you just have to go and just spark it up a little. (Interviewee \#33, personal communication, February $4^{\text {th }}, 2019$ )

In essence, here Interviewee \#33 expresses a line of thinking that was voiced by a number of respondents, and which can be used to sum up much of our discussion on tribal marketing: that both commercial marketers and political marketers strive to craft consumer tribes or brand tribes, 
but that it is typically easier to do so and to mobilize those tribes in the political context than in the commercial context. That finding is closely in line with what was hypothesized in $\mathrm{H}_{2}$ : political marketers are better suited than commercial marketers to craft and mobilize tribes due to political marketers' longstanding experience with mobilizing the small but energetic segments of the populace needed to win elections.

\section{Summary \& Conclusion}

To help pivot to our conclusion, Interviewee $\# 17$ offers some serious food for thought on the claim that data-based microtargeting strategies fuel tribal marketing for good or for bad:

I think, at some point, people have to be accountable for their own actions, right? So, certainly, political parties are guilty of, you know trying to fire up their supporters and targeting them on these volatile issues, you know, immigration (in the United States) is the obvious example, right? Getting people all inflamed about this. When really, I think the issues that they're usually talking about are tinkering at the margins, right? Nobody's actually suggesting any huge changes. But they just use these examples to rile each other up on both sides. It's really inflammatory; and it's really bad for any sort of meaningful discourse. (Interviewee \#17, personal communication, November $12^{\text {th }}, 2018$ )

Wise words that are becoming all the wiser now, with Election Day in a particularly visceral and virulent U.S. presidential campaign less than 100 days away.

In sum, the primary data courtesy of the thirty-three interviewees played the important role of laying out the respondents' thoughts on tribal marketing strategies and tactics and on the broader bidirectional flow of influence and innovation that I sought. Returning to my research question (which asked: what is the relationship between commercial marketers and political marketers and the practice of tribal marketing?), as of this writing and based upon the evidence provided by my interviewees, I can answer that we can see evidence of the bidirectional feedback loop of influence and innovation between commercial and political marketers and that, more specifically, political practitioners are ahead of their commercial counterparts regarding certain matters in the art of marketing — tribal marketing included. 


\section{Bibliography}

Arnhold, U. (2010). User Generated Branding: Integrating User Generated Content into Brand Management. Bremen, Germany: Gabler Verlag.

Atkin, D. (2004). The Culting of Brands: When Customers Become True Believers. New York, NY: Portfolio

Busby, R., \& Cronshaw, S. (2015). Political Branding: The Tea Party and its Use of Participation Branding. Journal of Political Marketing, 14(1/2), 96-110.

Butler, P., \& Harris, P. (2009). Considerations on the Evolution of Political Marketing Theory. Marketing Theory, 9(2), 149-164.

Chua, A. (2018). Political Tribes: Group Instinct and the Fate of Nations. New York, NY: Penguin Press.

Churchill, W. (1925/2009). Churchill's Wit: The Definitive Collection. R. M. Langworth (Ed.). London, U.K.: Ebury Press.

Cova, B., \& Cova, V. (2002). Tribal Marketing: The Tribalisation of Society and its Impact on the Conduct of Marketing. European Journal of Marketing, 36(5/6), 595-620.

Cova, B., Kozinets, R. V., \& Shankar, A. (2007). Tribes, Inc.: The New World of Tribalism. In B. Cova, R. V. Kozinets, \& A. Shankar (Eds.), Consumer Tribes (pp. 3-25). Oxford, U.K.: Butterworth-Heinemann.

Goldberg, J. (2018). Suicide of the West: How the Rebirth of Tribalism, Populism, Nationalism, and Identity Politics Is Destroying American Democracy. New York, NY: Crown Forum.

Holt, D. (2002). Why Do Brands Cause Trouble? A Dialectical Theory of Consumer Culture and Branding. Journal of Consumer Research, 29(1), 70-90.

Issenberg, S. (2012). The Victory Lab: The Secret Science of Winning Campaigns. New York, NY: Crown Publishers.

Keller, K.L. (2002). Branding and Brand Equity. In B.A. Weitz \& R. Wensley (Eds.), Handbook of Marketing. Thousand Oaks, CA: Sage.

Klein, N. (2000). No Logo. New York, NY: Picador.

Kreiss, D. (2016). Prototype Politics: Technology-Intensive Campaigning and the Data of Democracy. New York, N.Y.: Oxford University Press.

Mooney, K., \& Rollins, N. (2008). The Open Brand: When Push Comes to Pull in a Web-Made World. Berkeley, CA: New Riders. 
Muniz, A.M., \& O'Guinn, T.C. (2001). Brand Community. Journal of Consumer Research, 27(4), 412-432.

Newman, B. I. (2016). The Marketing Revolution in Politics: What Recent U.S. Presidential Campaigns Can Teach Us About Effective Marketing. Toronto, ON: Rotman-UTP Publishing.

Ostergaard, P. \& Jantzen, C. (2000). Shifting Perspectives in Consumer Research: From Buyer Behaviour to Consumption Studies, in S. Beckmann \& R. H. Elliott (Eds.), Interpretive Consumer Research: Paradigms, Methodologies \& Applications (pp. 9-23). Copenhagen: CBS Press.

Ries, A., \& Ries, L. (2002). The Fall of Advertising and the Rise of PR. New York, NY: HarperCollins.

Scammell, M. (2007). Political Brands and Consumer Citizens: The Rebranding of Tony Blair. The Annals of the American Academy of Political and Social Science, 611, 176-192.

Scammell, M. (2015). Politics and Image: The Conceptual Value of Branding. Journal of Political Marketing, 14(1/2), 7-18.

Serazio, M. (2017). Branding Politics: Emotion, Authenticity, and the Marketing Culture of American Political Communication. Journal of Consumer Culture, 17(2), 225-241.

Sharkey, T. (2012, January 25). What's Your Tribe? Tap into Your Core Consumers' Aspirations Like Nike, Gatorade, BabyCenter and REI Do. Forbes. Retrieved from: https://www.forbes.com/sites/tinasharkey/2012/01/25/whats-your-tribe-tap-into-yourcore-consumers-aspirations-like-nike-gatorade-babycenter-and-rei-do/\#141ccbdd304c

Tett, G. (2015). The Silo Effect: The Peril of Expertise and the Promise of Breaking Down Barriers. New York, N. Y.: Simon and Schuster Paperbacks.

Veroni, C. (2014). Spin: How Politics has the Power to Turn Marketing on Its Head. Toronto, ON: House of Anansi Press Inc.

Westen, D. (2007). The Political Brain: The Role of Emotion in Deciding the Fate of the Nation. New York, NY: Public Affairs. 